\title{
Short Communication: Suppressor of Cytokine Signaling-2 mRNA Increases After Parturition in the Liver of Dairy Cows
}

\author{
L. A. Winkelman, ${ }^{\star 1}$ M. C. Lucy,† T. H. Elsasser,ł J. L. Pate, ${ }^{*}$ and C. K. Reynolds ${ }^{\star 2,3}$ \\ *Department of Animal Sciences, The Ohio State University, Wooster 44691 \\ †The University of Missouri-Columbia, Columbia 65211 \\ ¥USDA Agricultural Research Service, Beltsville, MD 20705
}

\section{ABSTRACT}

After parturition, the somatotropic axis of the dairy cow is uncoupled, partly because of reduced concentration of liver-specific GH receptor (GHR) 1A. Estradiol$17 \beta\left(\mathrm{E}_{2}\right)$ concentrations increase at parturition and $\mathrm{E}_{2}$ upregulates suppressors of cytokine signaling-2 (SOCS2) mRNA expression, potentially inhibiting GH signaling. Therefore, we hypothesized that SOCS-2 mRNA is upregulated after parturition. Multiparous Holstein cows $(n=18)$ were dried off $45 \mathrm{~d}$ before expected parturition and fed diets to meet nutrient requirements at ad libitum or limited dry matter intake during the dry period. All cows were fed the same diet ad libitum from calving until 4 wk after parturition. Blood samples were collected weekly and more frequently near parturition. Liver biopsies obtained at $-21,-7,2$, and $28 \mathrm{~d}$ relative to parturition were assessed for SOCS-2 and GHR 1A mRNA by quantitative real-time reverse-transcription PCR. The relative amount of SOCS-2 mRNA increased after parturition with both treatments and was greater on $\mathrm{d} 2$ for cows limit-fed during the dry period compared with cows fed at ad libitum dry matter intake. Plasma $\mathrm{E}_{2}$ concentrations increased on $\mathrm{d}-13,-5$ and 1 relative to parturition and the increases were greater in limitfed cows. Plasma GH concentration was greater for limit-fed cows and increased after parturition in all cows. The amount of GHR 1A mRNA did not differ between diets but decreased on $d 2$. In addition to reduced GHR 1A, increased SOCS-2 mRNA after parturition, perhaps because of increased $\mathrm{E}_{2}$, may further uncouple GH signaling in the liver of the transition dairy cow.

\footnotetext{
Received June 11, 2007.

Accepted November 25, 2007.

${ }^{1}$ Current address: Department of Animal Sciences, Cornell University, Ithaca, NY.

${ }^{2}$ Corresponding author: c.k.reynolds@reading.ac.uk

${ }^{3}$ Current address: Department of Agriculture, The University of Reading, PO Box 237, Earley Gate, Reading, Berkshire, RG6 6AR, UK.
}

Key words: suppressors of cytokine signaling, dry period, limit-feeding, growth hormone receptor

During transition, and in particular immediately after parturition, the liver of the dairy cow becomes refractory to growth hormone $(\mathbf{G H})$, resulting in an uncoupling of the somatotropic axis (Kim et al., 2004) that is evidenced by reduced circulating concentrations of IGF-I despite increased plasma concentrations of GH. Different mechanisms may cause uncoupling of the somatotropic axis near parturition, including reduced concentrations of liver-specific GH receptor (GHR) 1A (Lucy et al., 2001). In addition, postreceptor alteration in GH signaling may occur via the actions of suppressors of cytokine signaling (SOCS) proteins (Krebs and Hilton, 2001). Several SOCS proteins interact with the Janus kinase and signal transducer and activators of transcription proteins, as well as the GHR to alter cytokine signal transduction (Starr et al., 1997). Suppressor of cytokine signaling mRNA expression is induced by a range of cytokines and hormones, including $\mathrm{GH}$ (Colson et al., 2000) and estradiol-17 $\beta$ ( $\mathbf{E}_{2}$; Leung et al., 2003; Leong et al., 2004), and plasma concentrations of $\mathrm{GH}$ and $\mathrm{E}_{2}$ increase near parturition in dairy cows (Radcliff et al., 2003).

We hypothesized that in addition to decreased liver GHR 1A (Kim et al., 2004), the uncoupling of the somatotropic axis during transition also results from increased SOCS, and specifically SOCS-2 because it is up-regulated by $\mathrm{E}_{2}$ (Leung et al., 2003; Leong et al., 2004). The objectives of the present study were to characterize changes in SOCS-2 mRNA expression during transition, and to determine if SOCS-2 mRNA expression is altered by limiting feed intake to meet nutrient and energy requirements during the dry period compared with ad libitum feeding before parturition.

All procedures were conducted following protocols approved by The Ohio State University Agricultural Animal Care and Use Committee. Details of the experimental design, dietary treatments, and sampling schedules are described elsewhere (Winkelman et al., 2008). Briefly, 18 multiparous Holstein cows paired by parity, 


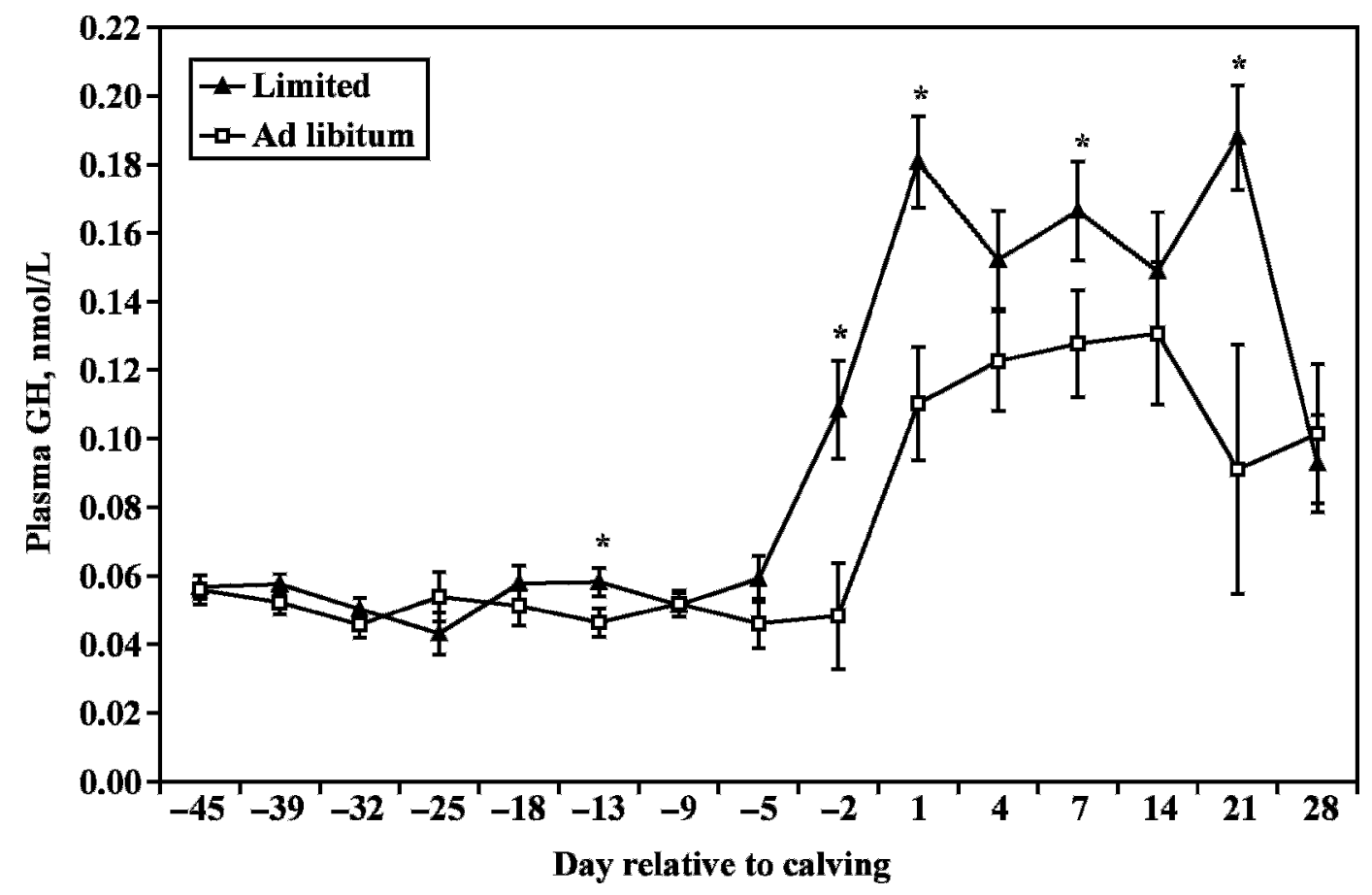

Figure 1. Effects of feeding diets at a limited or ad libitum DMI during the dry period on plasma growth hormone (GH) concentration. Data are least squares means and their standard errors. *Differences between treatments on specific days $(P<0.10)$; treatment, $P<0.003$; day, $P<0.001$; treatment $\times$ day interaction, $P<0.048$.

expected parturition date, and previous lactation performance were randomly assigned to 1 of 2 dietary treatments and dried off $45 \mathrm{~d}$ before expected parturition. The experimental diets were fed at either limited $(\mathbf{L})$ or ad libitum $(\mathbf{A L})$ intakes, formulated to meet (L) or exceed (AL) nutrient requirements. Liver biopsies were performed as described previously (Carlson et al., 2006) on $d-21 \pm 4$ and $d-7 \pm 4$ before parturition and on $\mathrm{d} 2$ and 28 after parturition. Part of the liver tissue was rapidly frozen in liquid nitrogen and part of the tissue was put into RNAlater (Ambion, Austin, TX). Frozen samples were stored at $-86^{\circ} \mathrm{C}$. Samples in RNAlater were incubated at $4^{\circ} \mathrm{C}$ overnight and then stored at $-20^{\circ} \mathrm{C}$.

Liver tissues stored in RNAlater were used for total RNA isolation using the SV Total RNA Isolation System (Promega Corporation, Madison, WI). Isolated RNA was stored at $-86^{\circ} \mathrm{C}$ until analysis. Concentration of RNA was determined by measuring absorbance at 260 $\mathrm{nm}$. Reverse transcription (RT)-PCR was performed on $2 \mu \mathrm{g}$ of total RNA using random hexamer primers and Superscript II reverse transcriptase (Invitrogen, Carlsbad, CA). The RT reaction was carried out in the Gene Amp PCR System 9700 (Applied Biosystems, Foster City, CA). The relative expression profile of SOCS-2 was determined by real-time quantitative PCR using the DNA Engine Monitor 2 (BioRad Laboratories, Her- cules, CA). Primers for SOCS-2 were validated in bovine mammary tissue as well as in liver tissue. Oligonucleotide primers for SOCS-2 were obtained from Qiagen Operon Biotechnologies (Alameda, CA) with the following sequences: forward primer 5'-GGGACTGCCTTTACCAACAA-3'; reverse primer 5'-GTGCTGGGACCTTTCACCTA-3' (Wall et al., 2005). Primers were diluted to a working concentration of $15 \mu M$ with nucleasefree water (Sigma-Aldrich Corp., St. Louis, MO). Two microliters of the cDNA reaction from RT-PCR was amplified in duplicate in a mixture containing $10 \mu \mathrm{L}$ of iQ SYBR Green Supermix (BioRad Laboratories), and 0.5 $\mu \mathrm{L}$ of a $15 \mu M$ solution of each forward and reverse primer was diluted to $20 \mu \mathrm{L}$ with nuclease-free water. Amplification was performed for a maximum of $40 \mathrm{cy}-$ cles (Leung et al., 2003; Wall et al., 2005) under the following conditions: denaturing at $94^{\circ} \mathrm{C}$ for $30 \mathrm{~s}$, annealing at $55^{\circ} \mathrm{C}$ for $30 \mathrm{~s}$, and extension at $72^{\circ} \mathrm{C}$ for 60 s. After PCR, the amplification products were electrophoretically separated on $1.5 \%$ agarose gels and visualized with ethidium bromide. Specific amplification of the gene of interest was noted by the presence of a single band of the expected size in the gel, as well as sequencing to confirm identity. A sample in which reverse transcriptase was not added was included to verify amplification of cDNA, not genomic DNA. Concentrations of SOCS-2 were normalized to $\beta$-actin mRNA 


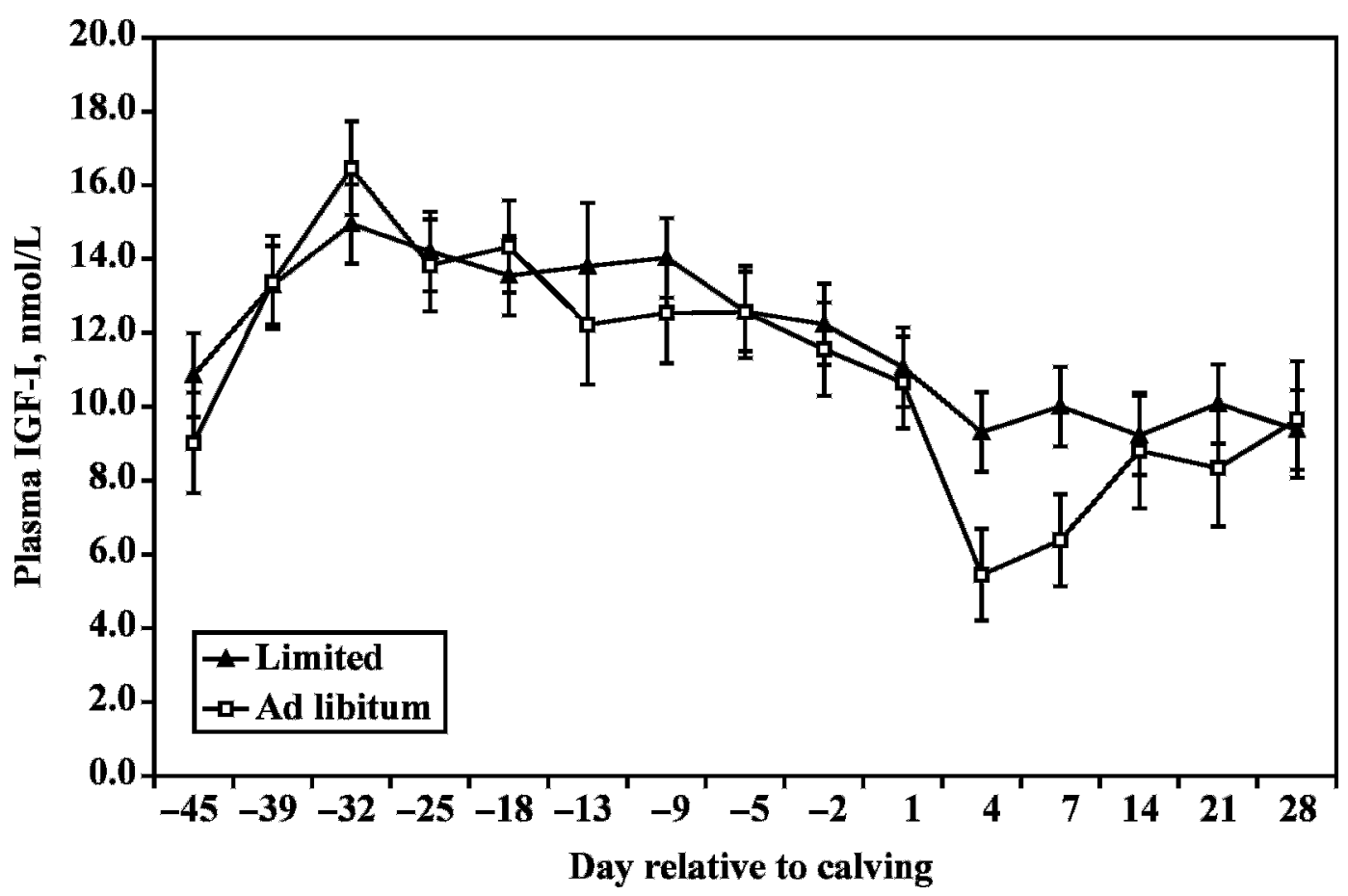

Figure 2. Effects of feeding diets at a limited or ad libitum DMI during the dry period on plasma IGF-I concentrations. Data are least squares means and their standard errors. Treatment, $P<0.324$; day, $P<0.001$; treatment by day interaction, $P<0.158$.

expression in the same sample to determine the relative changes in steady-state concentrations of SOCS-2 mRNA (Wall et al., 2005). Growth hormone receptor $1 \mathrm{~A}$ mRNA was measured as described previously (Jiang et al., 2005) after the integrity of RNA was confirmed by electrophoresis of an RNA aliquot from each sample. The relative amount of each mRNA was calculated using the delta $\mathrm{Ct}$ method.

Blood was collected weekly between 0800 and 1000 $\mathrm{h}$ via coccygeal venipuncture beginning at dry-off, approximately $45 \mathrm{~d}$ before expected due date. Samples were collected and plasma obtained and stored as described (Relling and Reynolds, 2007). To better characterize changes in concentrations of hormones and metabolites immediately before and after parturition (Winkelman et al., 2008), blood samples were collected more frequently using a jugular vein catheter (Relling and Reynolds, 2007) implanted on d -6 relative to parturition. More frequent blood sampling occurred on $d-5$, $-2,1,4$, and 7 relative to parturition, when samples were obtained 6 times at 90-min intervals each day, beginning at $0730 \mathrm{~h}$. Sampling then resumed a onceweekly schedule, with collection on d 14, 21, and 28 of lactation. On days when repeated samples were collected from the jugular vein, samples were pooled to reduce analytical requirements. For hormone analysis, all samples from one cow were included in the same assay run to eliminate interassay variation for analyses within cow, or all samples were run in one assay. Plasma concentrations of GH (Elsasser et al., 1989), IGF-I (Elsasser et al., 1989), and $\mathrm{E}_{2}$ (Anderson et al., 1996) were measured using RIA described previously. Intraassay CV was 9.3 and 8.0\%, respectively, for the IGF-I and GH assays. Samples analyzed for $\mathrm{E}_{2}$ were limited to $\mathrm{d}-39,-13,-5,-2,1$, and 28 for each cow based on previous reports of changes in plasma $\mathrm{E}_{2}$ concentrations during transition (e.g., Radcliff et al., 2003). Intraassay $\mathrm{CV}$ for $\mathrm{E}_{2}$ was $19.1 \%$ and interassay $\mathrm{CV}$ was $14.6 \%$.

One cow was biopsied only once because of suspected peritonitis following the first biopsy and 3 other cows did not complete the study because of problems unrelated to treatments (Winkelman et al., 2008). Only 10 cows completed all scheduled liver biopsies and blood samplings, but data obtained from the other 8 cows were included in the statistical analysis and results reported (Winkelman et al., 2008). For hormone analyses, data from all 18 cows were included for measurements obtained before calving; for postpartum data, the number of cows whose data were included in the statistical analysis was 9 for L and 6 for AL. Data analysis was carried out as repeated measures using the Mixed procedure (SAS Institute, 2003) and 1 of 5 covariance structures tested. The model for plasma 


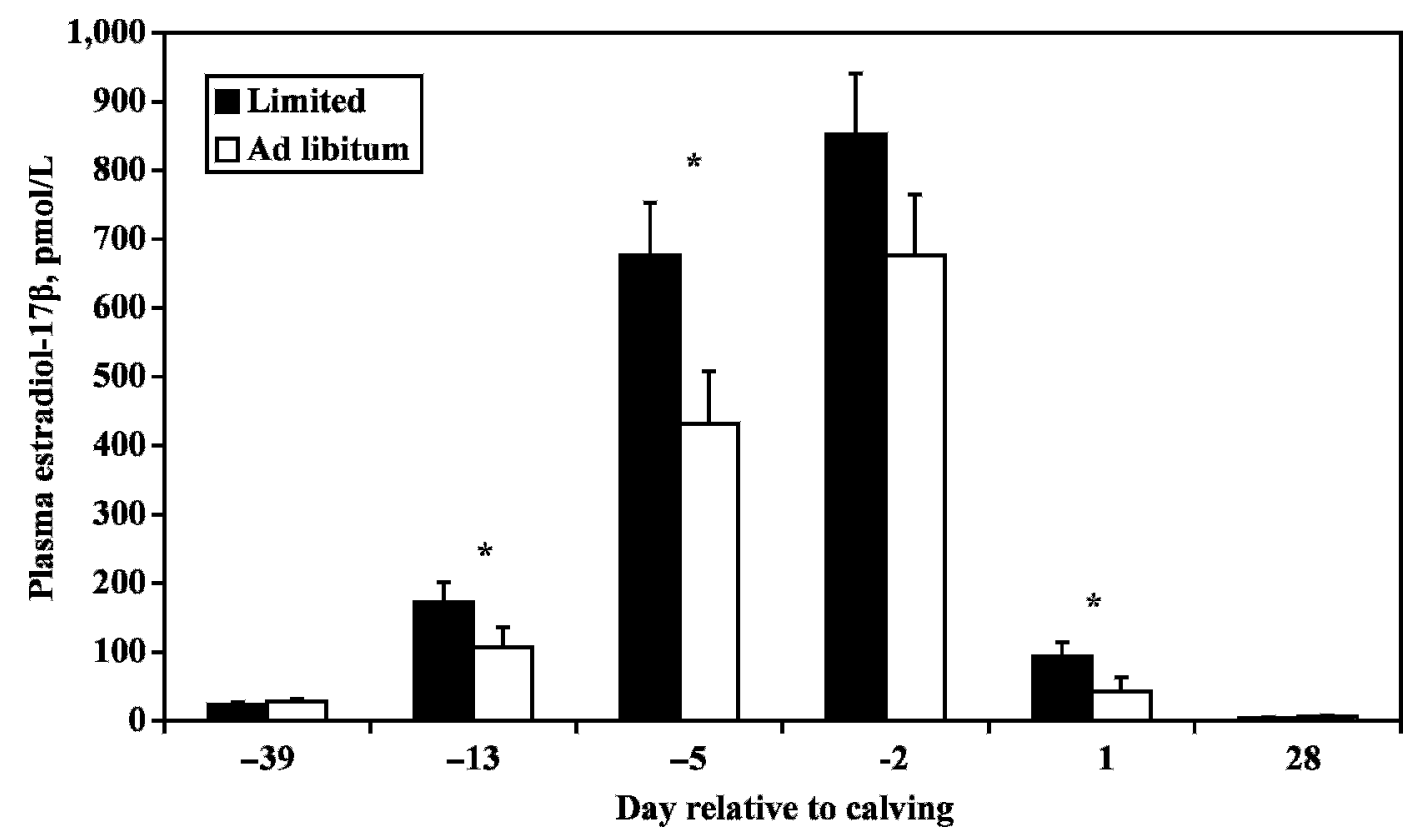

Figure 3. Effects of feeding diets at a limited or ad libitum DMI during the dry period on plasma estradiol-17 $\beta$ concentrations. Data are least squares means and their standard errors. *Differences between treatments on specific days $(P<0.10)$.

IGF-I and GH analyses included the main effects of treatment, period (pre- or postpartum), day within period, and parity. For $\mathrm{E}_{2}$, SOCS-2 mRNA, and GHR 1A mRNA, period was not included in the model. The 2and 3-way interactions of the main effects were tested as appropriate and the Slice option in the Mixed procedure was used to test for effects of diet at specific time points (SAS Institute, 2003). Because variance of the GHR 1A mRNA data was heterogeneous across sampling times, the arbitrary units measured were converted to their decadic logarithm for statistical analysis.

Plasma GH concentration was greater $(P=0.002)$ for $\mathrm{L}$ compared with $\mathrm{AL}$ after calving and on $\mathrm{d}-13$ and -2 relative to calving (Figure 1). For both $\mathrm{L}$ and AL, GH increased at parturition (Figure 1), but the increase observed in $\mathrm{L}$ cows began before parturition $(\mathrm{d}-2)$. Reasons for the earlier increase in plasma GH concentration before calving in $\mathrm{L}$ cows are not certain. The positive effect of dietary energy restriction on plasma $\mathrm{GH}$ concentration is well documented in growing animals (Elsasser et al., 1989), but in grazing cows fed to meet energy requirements during the dry period, plasma GH did not differ compared with cows fed greater amounts of DM and energy (Roche et al., 2005).

Plasma IGF-I (Figure 2) was not affected by treatment before $(P=0.99)$ or after parturition $(P=0.26)$, but decreased in the dry period as parturition approached. If plasma IGF-I concentrations were solely responsive to energy balance, then we would have ex- pected AL cows to have greater plasma IGF-I concentrations during the dry period as their energy balance was greater (Winkelman et al., 2008). When late-gestation cows were fed at a DMI that did not meet energy requirements, IGF-I concentrations before parturition were lower compared with cows fed at or above requirements (Roche et al., 2005). As in the present study, however, differences in diet energy intake at amounts above requirement did not alter plasma IGF-I concentration.

Plasma $\mathrm{E}_{2}$ concentration was greater for $\mathrm{L}(P<0.04$; Table 1) and increased near parturition for all cows (Figure 3). There tended to be a treatment by day interaction $(P=0.12)$, and $\mathrm{L}$ had greater $(P<0.10)$ plasma $\mathrm{E}_{2}$ concentrations on $d-13,-5$, and 1 (Figure 3 ). Increased plasma concentrations of $\mathrm{E}_{2}$ in $\mathrm{L}$ cows indicates that $\mathrm{DMI}$ and nutrient supply influence plasma $\mathrm{E}_{2}$ concentration. The mechanisms by which the amount of DMI altered plasma $\mathrm{E}_{2}$ concentration before parturition are not certain, but limit-feeding would reduce liver blood flow and clearance of steroid hormones from the blood (Sangsritavong et al., 2002), causing greater peripheral concentrations.

The relative abundance of SOCS-2 mRNA did not differ between treatments $(P=0.88$; Table 1$)$. Day had an effect on SOCS-2 mRNA abundance $(P<0.001$; Figure 4), and an interaction between treatment and day was observed $(P=0.01)$, with the greatest relative concentration occurring on $\mathrm{d} 2$ postpartum for L-fed cows $(P<0.001)$. The presence of SOCS-2 mRNA has been 
Table 1. Effect of prepartum diet on plasma concentration of estradiol-17 $\beta$ and relative abundance of suppressor of cytokine signaling-2 (SOCS-2) and growth hormone receptor (GHR) 1A mRNA in liver of dairy cows fed either a limited (L) or ad libitum (AL) basis before parturition ${ }^{1}$

\begin{tabular}{|c|c|c|c|c|c|c|}
\hline \multirow[b]{2}{*}{ Item } & \multicolumn{3}{|c|}{ Prepartum diet } & \multicolumn{3}{|c|}{$P$-value } \\
\hline & $\mathrm{L}$ & $\mathrm{AL}$ & SEM & Diet & Day & Diet $\times$ day \\
\hline Estradiol- $17 \beta, \mathrm{p} M$ & 303 & 215 & 26 & 0.031 & $<0.001$ & 0.118 \\
\hline SOCS-2 mRNA ${ }^{2}$ & 0.470 & 0.459 & 0.042 & 0.872 & $<0.001$ & 0.011 \\
\hline GHR 1A mRNA 3 & 203 & 249 & 144 & 0.851 & 0.176 & 0.933 \\
\hline GHR 1A mRNA ${ }^{4}$ & 1.595 & 1.957 & 0.276 & 0.367 & 0.006 & 0.245 \\
\hline
\end{tabular}

\footnotetext{
${ }^{1}$ Data are means across all prepartum and postpartum sampling days. All cows received the same diet after parturition.

${ }^{2}$ Relative abundance of SOCS-2 mRNA, normalized to $\beta$-actin.

${ }^{3}$ Values are expressed as the fold difference in arbitrary units relative to the expression from a medium control.

${ }^{4}$ Logarithm of arbitrary units.
}

reported in the mammary gland of dairy cows (Wall et al., 2005), but to our knowledge SOCS-2 mRNA has not been reported for the liver of dairy cows. Cows limit-fed during the dry period had greater relative abundance of SOCS- 2 mRNA on 2 postpartum than the AL cows (Figure 4). Limit-fed cows also had greater $\mathrm{E}_{2}$ concentrations on $\mathrm{d}-13,-5$, and $\mathrm{d} 1$ relative to parturition, and numerically greater $\mathrm{E}_{2}$ concentrations on $\mathrm{d}-2$ (Figure 3). Based on the known expression responsiveness of SOCS-2 to $\mathrm{E}_{2}$ in cell culture (Leong et al., 2004), a potential association exists between $\mathrm{E}_{2}$ concentration and SOCS-2 mRNA relative abundance in the liver of transition dairy cows. Short-term treatment of mice with a single $\mathrm{E}_{2}$ injection failed to up-regulate hepatic expression of SOCS-2 mRNA (Leong et al., 2004). In the same experiment, mice receiving $\mathrm{E}_{2}$ injections over the course of 3 wk had greater SOCS-2 mRNA in liver than controls, indicating that longer-term elevations of $\mathrm{E}_{2}$ are required to elevate SOCS-2 mRNA. This may explain why increases in $\mathrm{E}_{2}$ concentration on $\mathrm{d}-13$ and

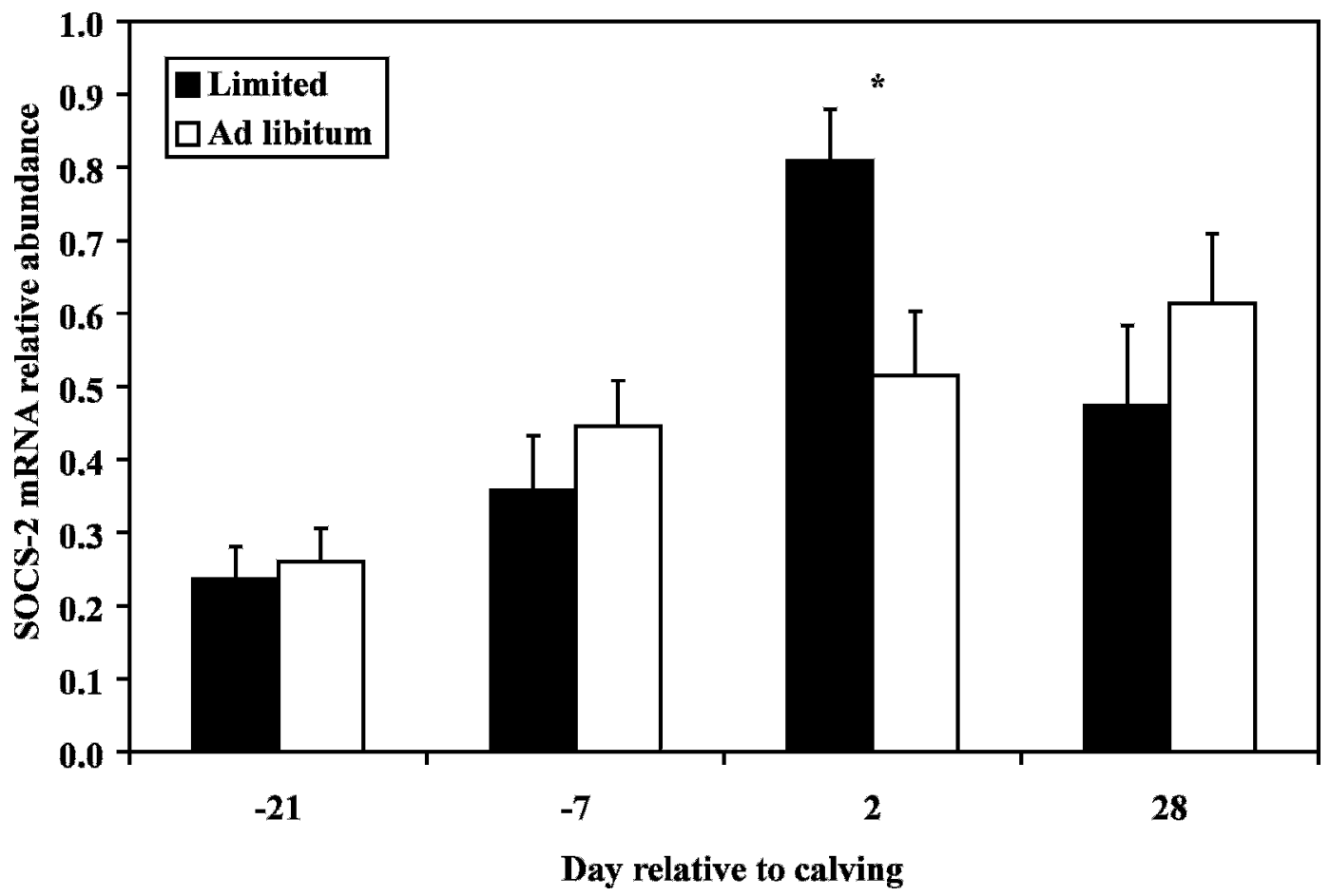

Figure 4. Effects of feeding diets at a limited or ad libitum DMI during the dry period on the relative abundance of liver suppressor of cytokine signaling-2 (SOCS-2) mRNA. Data are least squares means and their standard errors. *Differences between treatments on specific days $(P<0.10)$. 


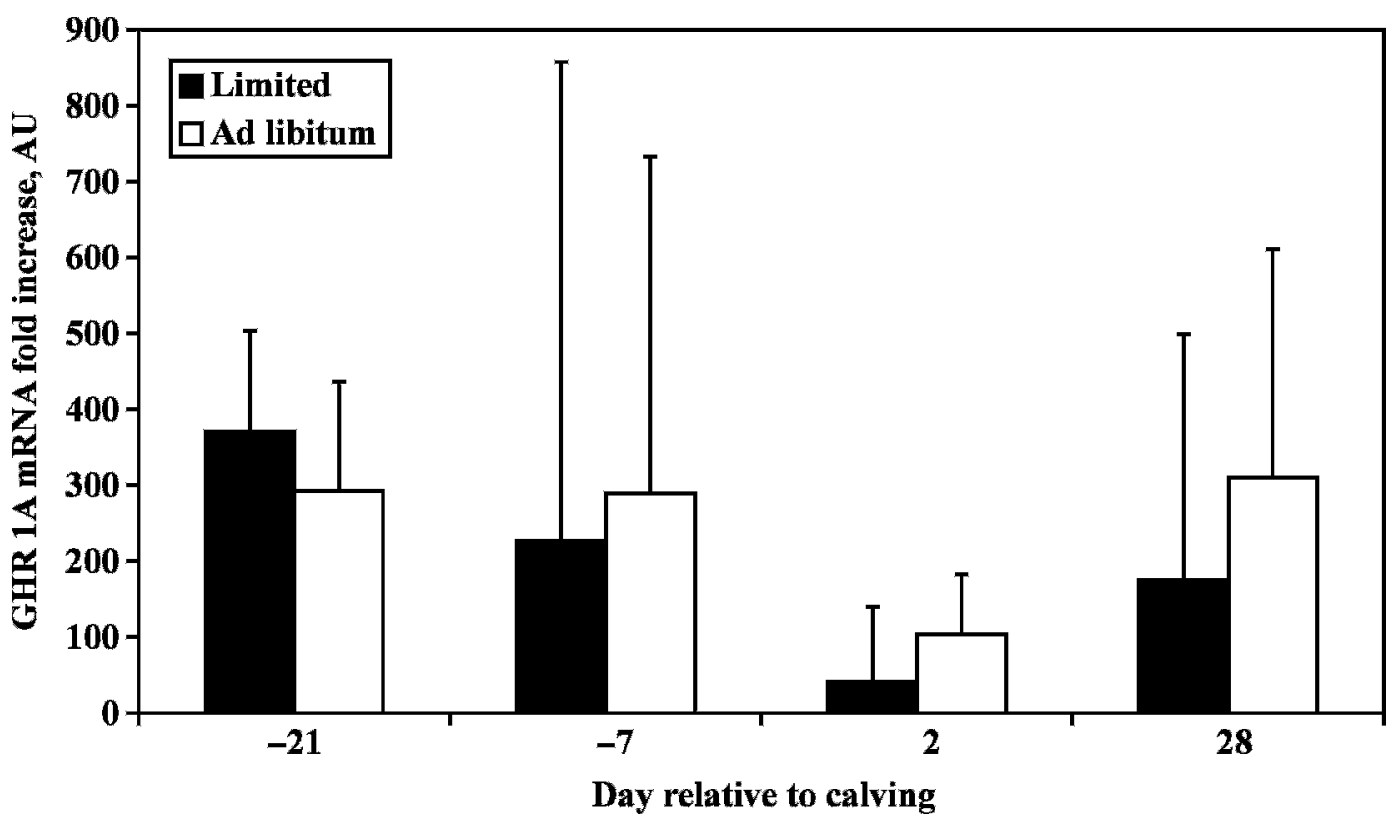

Figure 5. Effects of feeding diets at a limited or ad libitum DMI during the dry period on the relative abundance of growth hormone receptor (GHR) 1A mRNA. Values are expressed as the fold difference in arbitrary units (AU) relative to the expression from a medium control. Data are least squares means and their standard errors.

-5 of the present study (Figure 3 ) were not associated with increased SOCS-2 mRNA on d -7 (Figure 4). In addition to the potential influence of $\mathrm{E}_{2}$ on SOCS-2, increased concentrations of GH in L cows in the immediate postpartum period may also help to explain the increased SOCS-2 mRNA expression (Colson et al., 2000 ) that was observed in L cows on $d 2$.

Treatment did not affect the overall abundance of GHR 1A mRNA $(P=0.37$; Table 1$)$. Day affected $(P=$ 0.006) GHR 1A when the logarithms of the data were statistically analyzed, with GHR 1A mRNA abundance being lowest on d 2 after parturition. Amount of GHR 1A mRNA decreased by $72 \%$ from $d-7$ to $d 2$ across both treatments (Figure 5). These changes in liver GHR 1A mRNA amount confirm the decline in postpartum GHR 1A abundance reported previously (Radcliff et al., 2003; Kim et al., 2004; Jiang et al., 2005). The variability of liver expression of GHR 1A among individual cows has been noted previously (Radcliff et al., 2003). Reasons for this variability and the decrease in GHR 1A concentrations after parturition are not certain, but a possible role of elevated plasma $\mathrm{E}_{2}$ and other steroid hormones at parturition have been hypothesized (Radcliff et al., 2003). In addition, variation in the actual day relative to calving on which the biopsy was obtained also may have contributed to the variation in GHR 1A receptor amount observed at $d-7$ (Figure 5).

To conclude, the present research indicates that increased SOCS-2 in the liver may impair the ability of
GH to promote IGF-I production in the liver of the postpartum cow. The potential effects of increased plasma $\mathrm{E}_{2}$ on SOCS-2 mRNA expression in the liver of transition dairy cows merit further investigation.

\section{ACKNOWLEDGMENTS}

The authors extend appreciation to staff of the Ohio Agricultural Research and Development Center Krauss Dairy Farm for provision and care of the cows, J. Hanson for veterinary care and assistance with liver biopsies, and V. Cannon, A. Relling, D. Grum, and D. Wyatt for their technical assistance. Gratitude is extended to J. K. Drackley and N. B. Litherland of the University of Illinois for guidance with the liver biopsy procedure and the use of their biopsy trocar. Salaries and research support provided by state and federal funds appropriated to the Ohio Agricultural Research and Development Center, The Ohio State University (manuscript no. $17 / 07 \mathrm{AS})$.

\section{REFERENCES}

Anderson, L. H., C. M. McDowell, and M. L. Day. 1996. Progestininduced puberty and secretion of luteinizing hormone in heifers. Biol. Reprod. 54:1025-1031.

Carlson, D. B., N. B. Litherland, H. M. Dann, J. C. Woodworth, and J. K. Drackley. 2006. Metabolic effects of abomasal L-carnitine infusion and feed restriction in lactating Holstein cows. J. Dairy Sci. 89:4819-4834.

Colson, A., A. Le Cam, D. Maiter, M. Edery, and J. Thissen. 2000. Potentiation of growth hormone-induced liver suppressors of cy- 
tokine signaling messenger ribonucleic acid by cytokines. Endocrinology 141:3687-3695.

Elsasser, T. H., T. S. Rumsey, and A. C. Hammond. 1989. Influence of diet on basal and growth hormone-stimulated plasma concentrations of IGF-I in beef cattle. J. Anim. Sci. 67:128-141.

Jiang, H., M. C. Lucy, B. A. Crooker, and W. E. Beal. 2005. Expression of growth hormone receptor $1 \mathrm{~A} \mathrm{mRNA}$ is decreased in dairy cows but not in beef cows at parturition. J. Dairy Sci. 88:1370-1377.

Kim, J. W., R. P. Rhoads, S. S. Block, T. R. Overton, S. J. Frank, and Y. R. Boisclair. 2004. Dairy cows experience selective reduction of the hepatic growth hormone receptor during the periparturient period. J. Endocrinol. 181:281-290.

Krebs, D. L., and D. J. Hilton. 2001. SOCS proteins: Negative regulators of cytokine signaling. Stem Cells 19:378-387.

Leong, G. M., S. Moverare, J. Brce, N. Doyle, K. Sjögren, K. DahlmanWright, J. Gustafsson, K. K. Y. Ho, C. Ohlsson, and K. Leung. 2004. Estrogen up-regulates hepatic expression of suppressors of cytokine signaling-2 and -3 in vivo and in vitro. Endocrinology 145:5525-5531.

Leung, K. C., N. Doyle, M. Ballesteros, K. Sjögren, C. K. W. Watts, T. H. Low, G. M. Leong, R. J. M. Ross, and K. K. Y. Ho. 2003. Estrogen inhibits GH signaling by suppressing GH-induced JAK2 phosphorylation, an effect mediated by SOCS-2. Proc. Natl. Acad. Sci. USA 100:1016-1021.

Lucy, M. C., H. Jiang, and Y. Kobayashi. 2001. Changes in the somatotropic axis associated with the initiation of lactation. J. Dairy Sci. 84 (E Suppl.):E113-E119.

Radcliff, R. P., B. L. McCormack, B. A. Crooker, and M. C. Lucy. 2003. Plasma hormones and expression of growth hormone receptor and insulin-like growth factor-I mRNA in hepatic tissue of periparturient dairy cows. J. Dairy Sci. 86:3920-3926.

Relling, A. E., and C. K. Reynolds. 2007. Feeding rumen-inert fats differing in their degree of saturation decreases intake and increases plasma concentrations of gut peptides in lactating dairy cows. J. Dairy Sci. 90:1506-1515.

Roche, J. R., E. S. Kolver, and J. K. Kay. 2005. Influence of precalving feed allowance on periparturient metabolic and hormonal responses and milk production in grazing dairy cows. J. Dairy Sci. 88:677-689.

Sangsritavong, S., D. K. Combs, R. Sartori, L. E. Armentano, and M. C. Wiltbank. 2002. High feed intake increases liver blood flow and metabolism of progesterone and estradiol-17 $\beta$ in dairy cattle. J. Dairy Sci. 85:2831-2842.

SAS Institute. 2003. SAS User's Guide: Statistics. Version 8.0 ed. SAS Institute Inc., Cary, NC.

Starr, R., T. A. Willson, E. M. Viney, L. J. L. Murray, J. R. Rayner, B. J. Jenkins, T. J. Gonda, W. S. Alexander, D. Metcalf, N. A. Nicola, and D. J. Hilton. 1997. A family of cytokine-inducible inhibitors of signaling. Nature 387:917-921.

Wall, E. H., T. L. Auchtung-Montgomery, G. E. Dahl, and T. B. McFadden. 2005. Short-day photoperiod during the dry period decreases expression of suppressors of cytokine signaling in mammary gland of dairy cows. J. Dairy Sci. 88:3145-3148.

Winkelman, L. A., T. H. Elsasser, and C. K. Reynolds. 2008. Limitfeeding a high-energy diet to meet energy requirements in the dry period alters plasma metabolite concentrations but does not affect intake or milk production in early lactation. J. Dairy Sci. 91:1067-1079. 